\title{
Nominalių kainų tinkamumo Lietuvos miškų tikrajai vertei nustatyti vertinimas
}

\section{Stasys Mizaras,}

\section{Diana Lukminè}

Lietuvos agrariniu ir mišku mokslu centras, Instituto al. 1, LT-58344 Akademija, Kédainiu r. El.paštas stasys.mizaras@gmail.com
Lietuvos miškų ūkyje yra miškų, kaip turto, vertès atspindëjimo finansinëje apskaitoje problema. Valstybiné miškų tarnyba (VMT), vykdydama miškų kadastrą, vertina Lietuvos miškus nominalių kainų metodu. Pasigirsta siūlymų šiuos vertinimus pripažinti tikrąja miškų verte ir taikyti apskaitoje. Valdymo koordinavimo centras (VKC), analizuodamas miškų uredijų efektyvumą, jų miškus vertina diskontuotų pinigų srautų metodu. Šie vertinimai skiriasi daugiau nei 2 kartus.

Tyrimo tikslas - įvertinti Lietuvos miškų vertinimo nominalių kainų metodu tinkamumą tikrajai miškų vertei nustatyti. Uždaviniai: nustatyti miško žemès ir medynų tūrio vertinimo nominalių kainų metodu atitikimą tikrosios vertès nustatymo principams; atlikti miško žemès ir medynų tūrio palyginamus vertinimus nominalių kainų ir diskontuotų pinigų srautų metodais; palyginti brandžių medynų vertinimus nominalių kainų ir diskontuotų pinigų srautų metodais.

Nustatyta, kad VMT taikomas miškų vertinimo nominalių kainų metodas neatitinka tikrosios miškų vertès nustatymo principų, vertinimai nesusieti su medienos rinkos kainų tendencijomis. Pasaulinėje miškų vertinimo teorijoje ir praktikoje vyrauja miškų vertinimai diskontuotų pinigų srautų metodu, papildant juos kitais vertinimo būdais (rinkos, pajamų, išlaidų).

Raktažodžiai: miškai, piniginis vertinimas, nominali kaina, pinigų srautai, apskaita, diskonto norma

\section{IVADAS}

Pagal galiojantị Miškų ịstatymą ịvertinant miškų urédijų kapitalą, žemė ir miškas vertine išraiška ị apskaitą neittraukiami. Taip ì apskaitą nepatenka dalis svarbaus valstybei priklausančio turto. Siekiant spręsti šią problemą $2015 \mathrm{~m}$. liepos 3 d. LR aplinkos ministerija parenge Miškų îstatymo pakeitimo projektą, pagal kurị valstybinių miškų miško žemès ir medynų vertè būtų registruojami apskaitoje. Šiame projekte numatoma, kad VMT apskaičiuota valstybinių miškų miško žemès ir medynų verté, nustatyta vadovaujantis Žemès iqvertinimo metodika, patvirtinta Lietuvos Respublikos Vyriausybès $1999 \mathrm{~m}$. vasario $24 \mathrm{~d}$. nutarimu Nr. 205 „Dèl žemès ịvertinimo tvarkos“, pripažįstama šių miškų tikrąja miško žemès ir medynų verte. Kyla klausimas, ar daugiau nei prieš 20 metų sukurta metodika, grindžiama nominaliomis kainomis, gali būti taikoma nustatant tikrą̧ą miškų vertę. Be to, Lietuvoje naudojamos ir kitokios miškų vertinimo metodikos. VKC, analizuodamas valstybès imonių veiklą, miškus vertina diskontuotų pinigų srautų metodu. Šių vertinimų (VMT ir VKC) rezultatai skiriasi. Pagal VMT vertinimus, mišku urèdijų miškai 2013 m. gruodžio $31 \mathrm{~d}$. buvo ịkainoti 7883,7 mln. LTL (VMT, 2014), o pagal VKC skaičiavimus - $2971 \mathrm{mln}$. LTL (VKC, 2014). Skirtumas atsirado dèl taikomų metodų ypatumų.

Tikrosios turto vertes nustatymo principai ir metodai apibrèžti tarptautiniuose ir Lietuvos verslo apskaitos standartuose. Pagal 32-ąji verslo apskaitos standartą "Tikrosios vertès nustatymas“ (2014 m. gruodžio 18 d.) tikroji vertè - tai suma, už kurią 
vertès nustatymo dieną sandorio šalys viena kitai iprastomis rinkos sąlygomis gali parduoti turtą ar paslaugas (4 str.). Viešai skelbiama kaina, už kurią vertès nustatymo dieną būtų parduodamas turtas, vadinamoji rinkos kaina, yra laikoma geriausiu tikrosios vertès įverčiu (15 str.). Kad sandorio vertè būtų laikoma tikrąja turto verte, turi būti ịvykdytos šios sąlygos: šalys turi būti viena nuo kitos nepriklausomos, sandoris - nepriverstinis, šalys turi turèti visą reikiamą informaciją apie rinkos sąlygas ir kainas, šalys turi turèti lygias pozicijas rinkoje (Bajoriūnaitè, 2006). Nustatant turto ir įsipareigojimų tikrąją vertę, jei nèra viešai skelbiamos jų rinkos kainos, taikomi trys vertinimo metodai: lyginamasis (rinkos), išlaidų ir pajamų (32 verslo apskaitos standartas, 18 str.). Sprendžiant miškų tikrosios vertès nustatymo uždavinius (Jansson, Fagerström, 2003; Bigsby, Willemse, 2004; Penttinen et al., 2004; Ferguson, Leech, 2007; Penttinen, Rantala, 2008; Svensson et al., 2008; FPP, 2011; IVSC, 2012; IFA, 2012; Macedo, 2012; Lord, 2014) konstatuota, kad miškų tikrajai vertei nustatyti reikalingos aktyvios rinkos nèra pakankamai išplètotos. Todèl nustatant miškų tikrąją vertę be rinkos metoduc taikomi naudojimo pajamų (diskontuotų pinigų srautų) ir išlaidų metodai. Tarptautinè auditorių įmonè „PricewaterhouseCoopers“, atlikdama (FPP, 2011) nenukirsto miško tikrosios vertės nustatymo studiją, konstatavo, kad 18 iš 19 dalyvavusių studijoje kompanijų miškams vertinti taikè diskontuotų pinigų srautų metodą. Išlaidų metodas buvo taikomas naujai įveistiems miškams ar plantacijoms.

Šio tyrimo tikslas - jivertinti, ar Lietuvos miškų nominalios vertès atitinka paminètus tikrosios vertès nustatymo principus ir metodus.

Uždaviniai: 1) miškų vertinimo nominalių kainų metodų atitikimo tikrosios vertès nustatymo principams ir metodams apibūdinimas; 2) miško žemès ir medynų tūrio vertinimų nominalių kainų ir diskontuotu pinigų srautų metodais palyginimas; 3) valstybinių miškų vertinimų nominalios kainos ir diskontuotų pinigu srautų metodais palyginimas.

Tyrimo metodai: literatūros šaltinių ir dokumentų miškų piniginio vertinimo apskaitoje klausimais kokybiné analizé ir apibendrinimas; nominalios miško žemès ir medynų tūrio kainos nustatymo metodika; miško žemès ir medynų tūrio laukiamosios vertès nustatymo metodai; nenukirsto miško kainos nustatymo metodai.

\section{METODAI}

Nominalios kainos metodika. Nominali žemès kaina yra nustatoma atsižvelgiant ił kokybines žemés charakteristikas, o ne ị jos rinkos vertę (Aleknavičius, 2007). Po Nepriklausomybès atkūrimo (1990) vykdant žemès reformą LR Vyriausybė 1993 m. gruodžio 6 d. priemé nutarimą Nr. 909 dèl parduodamos valstybinès žemès ir valstybès išperkamos žemès nominalios kainos nustatymo ir jos taikymo tvarkos. Jame buvo pateikta ir miško žemès bei medynų tūrio vertinimo metodika.

Miško žemès vertè nustatyta kapitalizuojant vidutines grynąsias miškų ūkio pajamas ir diferencijuojant jas pagal augavietes priklausomai nuo ju produktyvumo:

$$
K_{a}=\frac{R \times I}{P}
$$

$K_{a}$ - augavietès miško žemès vertė;

$R$ - metinès vidutinès grynosios pajamos;

$P$ - kapitalizavimo norma;

$I$ - augavietes produktyvumo indeksas.

Medynų tūriai vertinti nenukirsto miško kainomis:

$$
K_{\mathrm{vid}}=V_{\mathrm{st}} \times k_{\mathrm{st}}+V_{\mathrm{vid}} \times k_{\mathrm{vid}}+V_{\mathrm{sm}} \times k_{\mathrm{sm}}+V_{\mathrm{m}} \times k_{\mathrm{m}}
$$

$K_{\text {vid }}$ - medynų tūrio vidutinè nenukirsto miško kaina;

$V_{\mathrm{st}}, V_{\text {vid}}, V_{\mathrm{sm}}, V_{\mathrm{m}}$ - stambios, vidutinès, smulkios padarinès medienos ir malkų tūrio dalis;

$k_{\mathrm{st}}, k_{\mathrm{vid}}, k_{\mathrm{sm}}, k_{\mathrm{m}}-$ stambios, vidutinès, smulkios padarinès medienos ir malkų nenukirsto miško kaina.

Miško žemès ir medynų tūrio nominalios kainos buvo nustatytos 1991 m. (Mizaras, 1993). Miško žemės vertè buvo apskaičiuota kapitalizuojant vidutines grynąsias pajamas iš 1 ha miško. Skaičiavimui naudoti duomenys: vidutinis metinis medienos tūrio prieaugis - 3,8 $\mathrm{m}^{3} / \mathrm{ha}(1988 \mathrm{~m}$. sausio $1 \mathrm{~d}$.), vidutinè medienos pardavimo kaina $-57 \mathrm{rb} / \mathrm{m}^{3}$, išlaidos $-47 \mathrm{rb} / \mathrm{m}^{3}$, grynosios metinès pajamos $-10 \mathrm{rb} / \mathrm{m}^{3}$ arba $38 \mathrm{rb} / \mathrm{ha}$. Taikyta $6 \%$ diskonto norma ir vidutinè miško žemès verte nustatyta $633 \mathrm{rb} / \mathrm{ha}$. Ši vidutinè miško žemès kaina diferencijuota pagal miško augavietes, remiantis miško žemès vertinimo skale (Mališauskas, 1975). Medynų tūrio vertinimai apskaičiuoti pagal medynų pasiskirstymą prekingumo kategorijomis 
(stambi, vidutiné, smulki padarinè, malkos) ir tuo metu galiojusias nenukirsto miško kainas. Vèliau šie vertinimai teisès aktų sudarytojų buvo keičiami dèl valiutų kaitos ir indeksuojami dèl infliacijos, tačiau 1991 m. užfiksuoti santykiai išliko. Tuo metu miško žemès rinkos apskritai nebuvo, medienos rinkos tik pradèjo formuotis.

Metodika vèliau buvo perkelta i $1999 \mathrm{~m}$. vasario 24 d. LR Vyriausybès nutarimą Nr. 205 „Dèl žemès vertinimo tvarkos" (aktualizuota $2014 \mathrm{~m}$. balandžio 24 d.). Šią metodiką dabar taiko VMT, vertindama Lietuvos miškus (miško žemès vertè indeksuota 1,6, o medynų tūrio - 4,8 karto). Vyriausybès nutarimais nustatyti miško žemès ir medynų tūrio vertinimai nominalios kainos metodu indeksuoti ir perskaičiuoti $\mathfrak{i}$ eurus, pateikti 1 ir 2 lentelèse.

\section{1 lentelè. Miško žemès nominali verté $\dot{e}^{\star} € /$ ha}

Table 1. Forest land value, $€ / \mathbf{h a}$

\begin{tabular}{cc}
\hline Augaviečių tipai / Site index & Vertè / Value \\
\hline$P_{a}$ & 29,2 \\
\hline$P_{a}{ }^{n}, P_{b}$ & 57,9 \\
\hline$U_{a}, P_{c}$ & 87,1 \\
\hline$\check{S}_{a}, P_{b}{ }^{n}, N_{a e}$ & 101,5 \\
\hline$U_{b}, P_{d}$ & 115,8 \\
\hline$N_{a}, L_{a}, U_{c}, P_{c}{ }^{n}$ & 130,2 \\
\hline$U_{d}$ & 145,0 \\
\hline$\check{S}_{b}, P_{d}{ }^{n}$ & 159,4 \\
\hline$U_{f}, \check{S}_{c}$ & 173,8 \\
\hline$\check{S}_{d}, N_{b}, L_{b}$ & 188,1 \\
\hline$L_{c}$ & 203,0 \\
\hline$N_{c}, L_{d}$ & 217,3 \\
\hline$N_{d}, L_{f}$ & 231,7 \\
\hline$N_{f}$ & 246,1 \\
\hline
\end{tabular}

* Apskaičiuota pagal LRV nutarimą „Dèl žemės įvertinimo tvarkos“ (1999 m. vasario 24 d. Nr. 205), aktualizuota 1995 m. vasario $1 \mathrm{~d}$.

Diskontuotų pinigu srautų metodai. Klasikiniai miško žemès ir medynų vertinimo metodai yra grindžiami grynųjų pajamų diskontavimu (Faustman, 1849; Mantel, 1982). Miško žemès laukiamosios vertès (Faustmano) formulè:

$$
Z=\frac{A_{T}+\sum D_{i} \times(1+p)^{T-i}-C \times(1+p)^{T}}{(1+p)^{T}-1}-\frac{v}{p} .
$$

Medyno laukiamosios vertès (Dieterich) formulè:

$$
M=\frac{A_{T}+\sum D_{i} \times(1+p)^{\mathrm{T}-i}}{(1+p)^{T-t}}
$$

$Z$ - miško žemès vertė; $A_{T}$ - pajamų, gaunamų iškirtus brandų medyną, vertè nenukirsto miško kainomis; $T$ - kirtimo apyvarta metais; $i$ - medyno amžius, kai vykdomi tarpiniai kirtimai; $D_{i}$ - tarpinių kirtimų pajamos medyno amžiuje $i$ nenukirsto miško kainomis; $C$ - miško atkūrimo (želdinimo ir kt.) išlaidos; $p$ - metinè palūkanų norma vieneto dalimis; $M$ - medyno laukiamoji verté; $t$ - vertinamojo medyno amžius; $v$ - metinès miškų administravimo ir priežiūros išlaidos.

Pagal formules $(3,4)$ vertinamas kiekvienas miško sklypas, o miško valdos vertè apskaičiuojama susumavus sklypų vertinimus. Miško valdų ar įmonių miškai gali būti vertinami ir pagal jų naudojimo diskontuotus metinius pinigu srautus taikant standartizuotas vertinimo formules (pvz., Verslo apskaitos 23-ias standartas „Turto nuvertejjimas"). VKC atlieka konsoliduotus visų miškų urèdijų miškų vertinimus diskontuotų pinigu srautu metodais.

Medynų tūrio vertinimas nenukirsto miško kainomis. Nenukirsto miško kainos skirtos kertamiems medynams ar medžiams vertinti. Pagal nenukirsto (anksčiau vadinto stačio) valstybinio miško kainų skaičiavimo metodiką (Mizaras, 1997) apskaičiuotos kainos buvo patvirtintos $1998 \mathrm{~m}$. rugsèjo $30 \mathrm{~d}$. LR aplinkos ministro ísakymu Nr. 194. Jos periodiškai indeksuojamos, priklausomai nuo besikeičiančių apvalios medienos rinkos kainų. Šiame tyrime taikyta $2015 \mathrm{~m}$. sausio $21 \mathrm{~d}$. indeksacija. Pagal ją apskaičiuotos nenukirsto miško kainos pateiktos 3 ir 4 lentelèse.

\section{REZULTATAI}

Miško žemės ir medynų tūrio vertinimas nominalių kainų metodu. Vertinta $\mathrm{Na}, \mathrm{Nb}, \mathrm{Nc}, \mathrm{Nd}$ augaviečių miško žemé ir pušynų $(\mathrm{Na}, \mathrm{Nb}, \mathrm{Nc}$ augavietès) bei ąžuolynų ( $\mathrm{Nd}$ augavietė) tūriai. Miško žemès vertè pagal nominalios kainos metodiką (1 lentelè): $\mathrm{Na}-130,2$ €/ha, $\mathrm{Nb}-188,1$; $\mathrm{Nc}-217,3, \mathrm{Nd}-231,7 € /$ ha.

Pušynų ( $\mathrm{Na}, \mathrm{Nb}, \mathrm{Nc}$ augavietės) ir ąžuolynų ( $\mathrm{Nd}$ augavietè) tūris ịvertintas (5 lentelè) pagal 2 lenteleje pateiktus vertinimus. 
2 lentelè. Medynų tūrio nominali verté $\dot{e}^{\star} € / \mathbf{m}^{3}$

Table 2. The nominal value of forest stand volume, $€ / \mathrm{m}^{3}$

\begin{tabular}{|c|c|c|c|c|c|c|}
\hline \multirow{2}{*}{$\begin{array}{l}\text { Vidutinis medynų } \\
\text { skersmuo cm } \\
\text { Average diameter }\end{array}$} & \multicolumn{6}{|c|}{ Medžių rūšys / Tree species } \\
\hline & $\begin{array}{l}\text { pušis, maumedis } \\
\text { Pine, larch }\end{array}$ & $\begin{array}{c}\text { eglè } \\
\text { Spruce }\end{array}$ & $\begin{array}{c}\text { ąžuolas, uosis } \\
\text { Oak, ash }\end{array}$ & $\begin{array}{l}\text { beržas, juodalksnis } \\
\text { Birch, black alder }\end{array}$ & $\begin{array}{l}\text { drebulè } \\
\text { Aspen }\end{array}$ & $\begin{array}{l}\text { baltalksnis } \\
\text { Grey alder }\end{array}$ \\
\hline 4 & 2,6 & 2,2 & 3,2 & 1,3 & 0,8 & 0,7 \\
\hline 8 & 5,3 & 4,7 & 6,3 & 2,5 & 1,7 & 1,3 \\
\hline 12 & 7,9 & 7,1 & 9,5 & 3,6 & 2,5 & 1,7 \\
\hline 16 & 10,1 & 9,2 & 12,5 & 5,0 & 2,9 & 1,8 \\
\hline 20 & 11,7 & 10,4 & 14,3 & 6,3 & 3,2 & 2,1 \\
\hline 24 & 13,2 & 11,4 & 16,4 & 7,1 & 3,3 & 2,2 \\
\hline 28 & 14,3 & 12,1 & 18,2 & 7,9 & 3,6 & - \\
\hline 32 & 15,3 & 12,8 & 19,2 & 8,3 & 3,8 & - \\
\hline 36 & 16,0 & 13,3 & 19,9 & - & 3,9 & - \\
\hline 40 & 16,4 & 13,5 & 20,2 & - & & - \\
\hline 44 & - & - & 20,3 & - & - & - \\
\hline 48 & - & - & 20,4 & - & - & - \\
\hline
\end{tabular}

* Apskaičiuota pagal LRV nutarimą „Dèl žemès įvertinimo tvarkos“ (1999 m. vasario 24 d. Nr. 205), aktualizuota 2001 m. gegužès 1 d.

3 lentelè. Nenukirsto valstybinio miško kainos $2015 \mathrm{~m}$. sausio $21 \mathrm{~d} . € / \mathrm{m}^{3}$

Table 3. Stumpage prices (21 January 2015)

\begin{tabular}{|c|c|c|c|c|}
\hline \multirow{2}{*}{$\begin{array}{l}\text { Medžių rūšys } \\
\text { Tree species }\end{array}$} & \multicolumn{3}{|c|}{$\begin{array}{l}\text { Stambumo grupès } \\
\text { Size groups }\end{array}$} & \multirow{2}{*}{$\begin{array}{l}\text { Malkinè mediena } \\
\text { Wood fuel }\end{array}$} \\
\hline & $\begin{array}{l}\text { stambi } \\
\text { Large }\end{array}$ & $\begin{array}{l}\text { vidutinè } \\
\text { Middle }\end{array}$ & $\begin{array}{c}\text { smulki } \\
\text { Small }\end{array}$ & \\
\hline $\begin{array}{l}\text { Pušis, maumedis } \\
\text { Pine, larch }\end{array}$ & 45,4 & 34,0 & 11,3 & 3,3 \\
\hline Eglè / Spruce & 46,6 & 32,3 & 6,3 & 2,3 \\
\hline Acžuolas / Oak & 135,8 & 117,0 & 98,5 & 5,9 \\
\hline $\begin{array}{l}\text { Uosis, klevas } \\
\text { Ash, maple }\end{array}$ & 89,2 & 63,1 & 33,7 & 5,9 \\
\hline Beržas / Birch & 37,6 & 23,5 & 11,1 & 4,3 \\
\hline $\begin{array}{l}\text { Juodalksnis, liepa, guoba, skroblas } \\
\text { Black alder, lime, elm, hornbeam }\end{array}$ & 29,9 & 22,7 & 5,6 & 2,3 \\
\hline Drebulè / Aspen & 13,6 & 11,5 & 6,2 & 1,5 \\
\hline $\begin{array}{l}\text { Baltalksnis, blindè } \\
\text { Grey alder, willow }\end{array}$ & 10,9 & 10,2 & 4,9 & 1,5 \\
\hline
\end{tabular}

Vidutinès medynų tūrio kainos, priklausomai nuo medynų skersmens, apskaičiuotos pagal medynų tūrio prekinę struktūrą (Kenstavičius, Kuliešis, 1983), pateiktos 4 lentelëje.

Miško žemès vertinimas pagal Faustmano formulę. Miško žemei vertinti pagal Faustmano formulę reikalingi duomenys: 1) brandžių medynų tūrio kaina; 2) tarpinių kirtimų pajamos, prolonguotos iki medynų kirtimo amžiaus; 3) miško atkūrimo išlaidos; 4) miškų administravimo ir priežiūros išlaidos.

Miško žemès vertinamos (Mališauskas, 1975) pagal tikslinių medynų produktyvumą. Šiame tyrime daryta prielaida, kad Na, Nb, Nc augavietèse 
4 lentelè. Vidutinè medynų tūrio nenukirsto miško kaina $2015 \mathrm{~m}$. sausio $21 \mathrm{~d} . € \mathbf{€} / \mathbf{m}^{3}$

Table 4. The average stumpage price of stand volume (21 January 2015)

\begin{tabular}{c|c|c|c|c|c|c|c|c}
\hline $\begin{array}{c}\text { Skersmuo } \\
\text { Diameter }\end{array}$ & $\begin{array}{c}\text { Pušis } \\
\text { Pine }\end{array}$ & $\begin{array}{c}\text { Eglè } \\
\text { Spruce }\end{array}$ & $\begin{array}{c}\text { Beržas } \\
\text { Birch }\end{array}$ & $\begin{array}{c}\text { Aqžuolas } \\
\text { Oak }\end{array}$ & $\begin{array}{c}\text { Uosis } \\
\text { Ash }\end{array}$ & $\begin{array}{c}\text { Drebulè } \\
\text { Aspen }\end{array}$ & $\begin{array}{c}\text { Juodalksnis } \\
\text { Black alder }\end{array}$ & $\begin{array}{c}\text { Baltalksnis } \\
\text { Grey alder }\end{array}$ \\
\hline 8 & 8 & 4 & 6 & 21 & 17 & 3 & 3 & 2 \\
\hline 12 & 14 & 11 & 9 & 49 & 23 & 5 & 6 & 3 \\
\hline 16 & 20 & 21 & 13 & 63 & 33 & 6 & 9 & 4 \\
\hline 20 & 25 & 26 & 16 & 72 & 39 & 7 & 11 & 5 \\
\hline 24 & 29 & 30 & 19 & 80 & 46 & 6 & 13 & 6 \\
\hline 28 & 32 & 32 & 21 & 88 & 53 & 6 & 13 & \\
\hline 32 & 34 & 35 & 23 & 93 & 57 & 6 & 13 & \\
\hline 36 & 36 & 36 & 24 & 95 & 61 & 6 & 11 & \\
\hline 40 & 37 & 36 & 96 & 63 & & & \\
\hline 44 & 37 & & 97
\end{tabular}

5 lentelè. Medynų tūrio (skalsumas $\mathbf{0 , 7 ^ { \star }}$ ) vertinimas nominalių kainų metodu

Table 5. The valuation of forest stand volume according to the nominal price method (stocking level 0.7)

\begin{tabular}{|c|c|c|c|c|c|c|c|c|c|c|c|c|c|c|c|c|}
\hline \multirow[b]{2}{*}{ 总 } & \multicolumn{4}{|c|}{$\begin{array}{l}\text { Pušynai (Na) } \\
\text { Pine }\end{array}$} & \multicolumn{4}{|c|}{$\begin{array}{c}\text { Pušynai (Nb) } \\
\text { Pine }\end{array}$} & \multicolumn{4}{|c|}{$\begin{array}{l}\text { Pušynai (Nc) } \\
\text { Pine }\end{array}$} & \multicolumn{4}{|c|}{$\begin{array}{c}\text { Acžuolynai (Nd) } \\
\text { Oak }\end{array}$} \\
\hline & 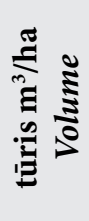 & 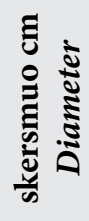 & 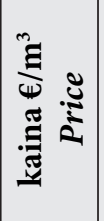 & 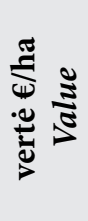 & 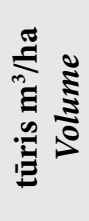 & 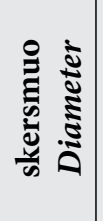 & 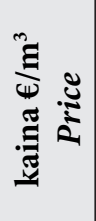 & 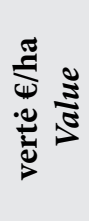 & 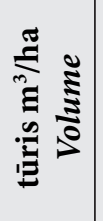 & 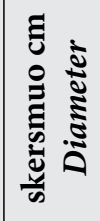 & 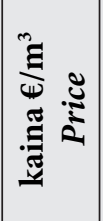 & 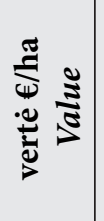 & 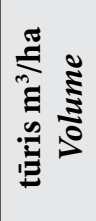 & 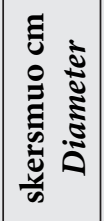 & 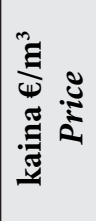 & 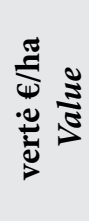 \\
\hline 20 & 29 & 6,5 & 4,4 & 128 & 68 & 8,9 & 6,0 & 408 & 53 & 10,1 & 6,8 & 360 & 45 & 6,5 & 5,3 & 239 \\
\hline 30 & 57 & 10,5 & 7,0 & 399 & 115 & 14,0 & 9,0 & 1035 & 134 & 15,7 & 9,8 & 1313 & 84 & 11,2 & 9,0 & 756 \\
\hline 40 & 87 & 14,2 & 9,1 & 792 & 159 & 18,6 & 11,2 & 1781 & 186 & 20,7 & 12,0 & 2232 & 122 & 15,8 & 12,1 & 1476 \\
\hline 50 & 116 & 17,4 & 10,6 & 1230 & 200 & 22,6 & 12,7 & 2540 & 233 & 25,1 & 13,5 & 3146 & 158 & 20,3 & 14,7 & 2323 \\
\hline 60 & 142 & 20,3 & 11,9 & 1690 & 236 & 26,2 & 13,9 & 3280 & 275 & 29,0 & 14,6 & 4015 & 192 & 24,7 & 16,8 & 3226 \\
\hline 70 & 165 & 22,8 & 12,8 & 2112 & 267 & 29,3 & 14,7 & 3925 & 311 & 32,4 & 15,4 & 4789 & 223 & 29,0 & 18,4 & 4103 \\
\hline 80 & 184 & 25,0 & 13,5 & 2484 & 293 & 32,0 & 15,3 & 4483 & 341 & 35,4 & 15,9 & 5422 & 250 & 33,1 & 19,6 & 4900 \\
\hline 90 & 201 & 26,9 & 14,1 & 2834 & 314 & 34,4 & 15,7 & 4930 & 365 & 38,0 & 16,2 & 5913 & 274 & 37,0 & 20,3 & 5562 \\
\hline 100 & 215 & 28,6 & 14,5 & 3118 & 332 & 36,5 & 16,0 & 5312 & 385 & 40,3 & 16,5 & 6353 & 294 & 40,7 & 20,7 & 6086 \\
\hline 110 & & & & & & & & & & & & & 311 & 44,1 & 20,9 & 6500 \\
\hline 120 & & & & & & & & & & & & & 325 & 47,3 & 20,8 & 6760 \\
\hline
\end{tabular}

Medynų tūris ir skersmuo (Kuliešis, 1993); augaviečių našumo indeksai: pušynai $\mathrm{Na}-21, \mathrm{Nb}-27, \mathrm{Nc}-30$, ąžuolynai $\mathrm{Nd}-27$ (VMT, 2010).

tokie yra 1,0 skalsumo pušynai, o $\mathrm{Nd}$ augavietèje - ąžuolynai, panaudojant $75 \%$ iškrentančio tūrio. 6 lentelèje apskaičiuota tikslinių brandžių medynų tūrio vertè naudojant 1,0 skalsumo medynų dinamikos modelius (Kuliešis, 1993), medynų tūrio prekinę struktūrą (Kenstavičius, Ku- liešis, 1983) ir $2015 \mathrm{~m}$. sausio $21 \mathrm{~d}$. nenukirsto miško kainas.

Tarpinių kirtimų pajamos, prolonguotos iki medynų kirtimo amžiaus, pateiktos 7 lenteleje. Jos apskaičiuotos pagal 1,0 skalsumo medynų dinamikos modelius (Kuliešis, 1993) vertinant visą 
6 lentelè. Brandžių medynų tūrio (skalsumas - 1,0) įvertinimas

Table 6. Evaluation of mature stand volume (stocking level 1.0)

\begin{tabular}{|c|c|c|c|c|c|c|c|}
\hline $\begin{array}{l}\text { Augavietė } \\
\text { Site index }\end{array}$ & $\begin{array}{c}\text { Tikslinè } \\
\text { medžių } \\
\text { rūšis } \\
\text { Tree species }\end{array}$ & $\begin{array}{c}\text { Augavietès } \\
\text { našumo indeksas } \\
\text { Site productivity } \\
\text { index }\end{array}$ & $\begin{array}{l}\text { Kirtimo } \\
\text { amžius } \\
\text { Cutting } \\
\text { age }\end{array}$ & $\begin{array}{c}\text { Skersmuo } \\
\mathrm{cm}^{\star *} \\
\text { Diameter }\end{array}$ & $\begin{array}{c}\text { Tūris } \\
\text { m³ }^{3} / \mathbf{h a}^{* *} \\
\text { Volume }\end{array}$ & $\begin{array}{c}\text { Kaina } \\
€ / \text { ha }^{* * *} \\
\text { Price }\end{array}$ & $\begin{array}{c}\text { Tūrio vertè } \\
€ / \text { ha } \\
\text { Volume } \\
\text { value }\end{array}$ \\
\hline $\mathrm{Na}$ & $\mathrm{P}$ & 21 & 100 & 25,5 & 334 & 30,1 & 10053 \\
\hline $\mathrm{Nb}$ & $\mathrm{P}$ & 27 & 100 & 32,4 & 474 & 34,2 & 16211 \\
\hline $\mathrm{Nc}$ & $\mathrm{P}$ & 30 & 100 & 35,7 & 551 & 35,9 & 19781 \\
\hline $\mathrm{Nd}$ & A & 27 & 120 & 42,3 & 464 & 97,0 & 45008 \\
\hline
\end{tabular}

*VMT, 2010;

** Kuliešis, 1993;

*** vidutinès kainos, apskaičiuotos pagal medynų tūrio prekinę struktūrą (Kenstavičius, Kuliešis, 1983) ir nenukirsto miško kainas, indeksuotas 2015 m. sausio $21 \mathrm{~d}$.

7 lentelè. Tarpinių kirtimų pajamų pagal kirtimų apyvartą apskaičiavimas

Table 7. Calculation of thinning income during the cutting period

\begin{tabular}{|c|c|c|c|c|c|c|}
\hline $\begin{array}{c}\text { Metai } \\
\text { Year }\end{array}$ & $\begin{array}{c}\text { Skersmuo* }^{*} \mathrm{~cm} \\
\text { Diameter }\end{array}$ & $\begin{array}{c}\text { Iškrentantis } \\
\text { ir iškertamas } \\
\text { tūris* } \mathbf{m}^{3} / \mathrm{ha} \\
\text { Drain volume }\end{array}$ & $\begin{array}{c}\text { Kaina }^{\star *} € / \mathbf{m}^{3} \\
\text { Price }\end{array}$ & $\begin{array}{c}\text { Vertè } € / \text { ha } \\
\text { Value }\end{array}$ & $\begin{array}{c}\text { Prolongavimo } \\
\text { koeficientai } \\
\text { Coefficient of } \\
\text { prolongation }\end{array}$ & $\begin{array}{c}\text { Prolonguota } \\
\text { vertė } € / \text { ha } \\
\text { Value }\end{array}$ \\
\hline \multicolumn{7}{|c|}{ Pušynai; Na augavietè / Pine Na site index } \\
\hline $20-30$ & 4,7 & 24 & 3,8 & 91 & 9,1789 & 835 \\
\hline $30-40$ & 8,2 & 33 & 6,5 & 218 & 6,8300 & 1489 \\
\hline $40-50$ & 11,3 & 35 & 10,4 & 364 & 5,0821 & 1850 \\
\hline $50-60$ & 14,0 & 35 & 13,6 & 476 & 3,7816 & 1800 \\
\hline $60-70$ & 16,6 & 34 & 16,6 & 564 & 16,6 & 1587 \\
\hline $70-80$ & 19,0 & 33 & 19,0 & 627 & 2,0938 & 1313 \\
\hline $80-90$ & 21,4 & 32 & 21,1 & 675 & 1,5580 & 1052 \\
\hline $90-100$ & 23,4 & 30 & 22,7 & 681 & 1,1593 & 789 \\
\hline $\begin{array}{l}\text { Suma } \\
\text { Total }\end{array}$ & & 256 & & 3696 & & 10715 \\
\hline \multicolumn{7}{|c|}{ Pušynai; $\mathrm{Nb}$ augaviete / Pine $\mathrm{Nb}$ site index } \\
\hline $20-30$ & 6,5 & 34 & 5,2 & 177 & 9,1789 & 1625 \\
\hline $30-40$ & 10,5 & 41 & 9,4 & 385 & 6,8300 & 2630 \\
\hline $40-50$ & 14,0 & 43 & 13,6 & 585 & 5,0821 & 2973 \\
\hline $50-60$ & 17,2 & 43 & 17,2 & 740 & 3,7816 & 2798 \\
\hline $60-70$ & 20,1 & 41 & 20,1 & 24 & 2,8139 & 2319 \\
\hline $70-80$ & 23,0 & 40 & 22,4 & 896 & 2,0938 & 1876 \\
\hline $80-90$ & 25,9 & 38 & 24,3 & 923 & 1,5580 & 1438 \\
\hline $90-100$ & 28,7 & 37 & 25,9 & 958 & 1,1593 & 1111 \\
\hline $\begin{array}{l}\text { Suma } \\
\text { Total }\end{array}$ & & 317 & & 5488 & & 16770 \\
\hline \multicolumn{7}{|c|}{ Pušynai; Nc augaviete / Pine Nc site index } \\
\hline $20-30$ & 7,2 & 38 & 5,8 & 220 & 9,1789 & 2019 \\
\hline $30-40$ & 11,4 & 45 & 10,5 & 473 & 6,8300 & 3231 \\
\hline
\end{tabular}




\begin{tabular}{ccccccc}
\hline & & & & & & \\
\hline $40-50$ & 13,3 & 46 & 12,8 & 789 & 39821 & 2993 \\
\hline $50-60$ & 16,8 & 46 & 16,8 & 8847816 & 2923 \\
\hline $60-70$ & 20,1 & 44 & 20,1 & 2,8139 & 2487 \\
\hline $70-80$ & 23,2 & 43 & 22,6 & 972 & 2,0938 & 2035 \\
\hline $80-90$ & 26,3 & 41 & 24,6 & 1009 & 1,5580 & 1572 \\
\hline $90-100$ & 29,4 & 40 & 26,2 & 1048 & 1,1593 & 1215 \\
\hline $\begin{array}{c}\text { Suma } \\
\text { Total }\end{array}$ & & 343 & 5968 & & 18475 \\
\hline
\end{tabular}

\begin{tabular}{ccccccc}
\hline \multicolumn{7}{c}{ Ačzuolynai; Nd augavietė / Oak Nd site index } \\
\hline $20-30$ & 4,6 & 22 & 17,2 & 378 & 16,5782 & 6267 \\
\hline $30-40$ & 8,4 & 35 & 29,6 & 1036 & 12,3357 & 12780 \\
\hline $40-50$ & 12,1 & 41 & 40,2 & 1648 & 9,1789 & 15127 \\
\hline $50-60$ & 15,5 & 44 & 48,6 & 2138 & 6,8300 & 14603 \\
\hline $60-70$ & 18,7 & 44 & 55,5 & 2442 & 5,0821 & 12410 \\
\hline $70-80$ & 21,7 & 43 & 61,0 & 2623 & 3,7816 & 9919 \\
\hline $80-90$ & 24,6 & 41 & 65,6 & 2690 & 2,8139 & 7569 \\
\hline $90-100$ & 27,4 & 39 & 69,4 & 2707 & 2,0938 & 5668 \\
\hline $100-110$ & 30,2 & 37 & 72,5 & 2683 & 1,5580 & 4180 \\
\hline $110-120$ & 33,1 & 35 & 75,0 & 2625 & 1,1593 & 3043 \\
\hline Suma / Total & & 381 & & 20970 & & 91566 \\
\hline
\end{tabular}

* Kuliešis, 1993. Pagal augaviečių našumo indeksus: pušynai Na - 21, Nb - 27, Nc - 30, ąžuolynai Nd - 27 (VMT, 2010);

** valstybinio nenukirsto miško kainos $1915 \mathrm{~m}$. sausio $21 \mathrm{~d}$.

iškrentantị tūrị pagal medžių prekingumo lenteles ir $2015 \mathrm{~m}$. sausio $21 \mathrm{~d}$. nenukirsto miško kainas, sumažintas $20 \%$ dèl tarpinių kirtimų medienos kokybès.

Miško žemès laukiamoji vertė pagal Faustmano formulę pateikta 8 lentelejje.

Medynų tūrio vertinimas pagal Dieterich formulę. Medynų tūriai $\mathrm{Na}, \mathrm{Nb}, \mathrm{Nc}, \mathrm{Nd}$ augavietè- se įvertinti (9 lentelè) laukiamų pajamų metodu (2 formulè). Taikytas scenarijus: medynų skalsumas 0,7, tarpiniais kirtimais panaudojama $50 \%$ iškrentančio medynų tūrio.

VMT ir VKC vertinimų palyginimas. Miškų vertinimų nominaliomis kainomis ir diskontuotu pinigų srautų metodais palyginimui (10 lentelè) panaudoti VMT ir VKC duomenys. Nominalios

8 lentelè. Miško žemès laukiamoji vertè pagal Faustmano formulę €/ha (žymėjimai pagal 3 formulę)

Table 8. The forest land expectation value by Faustman formula, $€ /$ ha

\begin{tabular}{c|ccc|c|c|ccc}
\hline $\begin{array}{c}\text { Augavieté } \\
\text { Site } \text { index }\end{array}$ & $\boldsymbol{A}_{T}^{*}$ & $\sum\left(D_{i} \times(1+p)^{T-i}\right)_{\star *}$ & $\mathbf{C}^{* * *}$ & $(\mathbf{1}+\boldsymbol{p})^{T}$ & $(\mathbf{1}+\boldsymbol{p})^{T} \mathbf{1}$ & $\boldsymbol{v} / \boldsymbol{p}^{* * * *}$ & $\boldsymbol{Z}$ \\
\hline $\mathrm{Na}$ & 10053 & 8036 & 508 & 19,2186 & 18,2186 & 417 & 40 \\
\hline $\mathrm{Nb}$ & 16211 & 12578 & 508 & 19,2186 & 18,2186 & 417 & 627 \\
\hline $\mathrm{Nc}$ & 19781 & 13856 & 508 & 19,2186 & 18,2186 & 417 & 825 \\
\hline $\mathrm{Nd}$ & 45008 & 68675 & 837 & 34,7109 & 33,7109 & 417 & 2093 \\
\hline
\end{tabular}

* Pateikta 6 lentelèje;

** pateikta 7 lentelèje ir padauginta iš 0,75 dèl iškrentančio tūrio panaudojimo dalies;

*** miško atkūrimo išlaidos (Riepšas, Laurinavičius, 2009); 41 \%, tenkantis medienai kompleksinės miškų vertès (Mizaras ir kt., 2015);

**** $v-2011 \mathrm{~m}$. miškų urèdijų bendros ir administracinės, girininkijų ir miškų priežiūros personalo, miškų sanitarinės ir priešgaisrinès apsaugos išlaidos - 30,6 €/ha, $41 \%$, tenkantis medienai kompleksinès miškų vertès $(12,5 € / h a), p=3 \%$. 
9 lentelè. Medynų tūrio vertẻ pagal Dieterich formulę (žymèjimai pagal 4 formulę) $\mathbf{\epsilon} / \mathbf{h a}$

Table 9. The value of stand volume according to the Dieterich formula

\begin{tabular}{|c|c|c|c|c|}
\hline $\begin{array}{l}\text { Amžius, metai } \\
\text { Age, years }\end{array}$ & $A_{T}^{*}$ & $\sum\left(D_{i} \times(1+p)^{T-i}\right)^{\star \star}$ & $(1+p)^{T-t}$ & $M$ \\
\hline \multicolumn{5}{|c|}{ Pušynai; $\mathrm{Na}$ augavietè / Pine Na site index } \\
\hline 10 & 7037 & 3750 & 14,3005 & 754 \\
\hline 20 & 7037 & 3750 & 11,6409 & 927 \\
\hline 30 & 7037 & 3458 & 7,9178 & 1325 \\
\hline 40 & 7037 & 2937 & 5,8916 & 1693 \\
\hline 50 & 7037 & 2289 & 4,3839 & 2127 \\
\hline 60 & 7037 & 1659 & 3,2620 & 2666 \\
\hline 70 & 7037 & 1104 & 2,4273 & 3354 \\
\hline 80 & 7037 & 644 & 1,8061 & 4252 \\
\hline 90 & 7037 & 276 & 1,3439 & 5442 \\
\hline 100 & 7037 & - & 1,0000 & 7037 \\
\hline \multicolumn{5}{|c|}{ Pušynai; $\mathrm{Nb}$ augavietè / Pine $\mathrm{Nb}$ site index } \\
\hline 10 & 11348 & 5870 & 14,3005 & 1204 \\
\hline 20 & 11348 & 5870 & 11,6409 & 1479 \\
\hline 30 & 11348 & 5301 & 7,9178 & 2103 \\
\hline 40 & 11348 & 4381 & 5,8916 & 2670 \\
\hline 50 & 11348 & 3340 & 4,3839 & 3350 \\
\hline 60 & 11348 & 2360 & 3,2620 & 4202 \\
\hline 70 & 11348 & 1548 & 2,4273 & 5313 \\
\hline 80 & 11348 & 891 & 1,8061 & 6776 \\
\hline 90 & 11348 & 388 & 1,3439 & 8733 \\
\hline 100 & 11348 & - & 1,0000 & 11348 \\
\hline \multicolumn{5}{|c|}{ Pušynai; Nc augavietè / Pine Nc site index } \\
\hline 10 & 13847 & 6466 & 14,3005 & 1420 \\
\hline 20 & 13847 & 6466 & 11,6409 & 1745 \\
\hline 30 & 13847 & 5759 & 7,9178 & 2476 \\
\hline 40 & 13847 & 4628 & 5,8916 & 3136 \\
\hline 50 & 13847 & 3580 & 4,3839 & 3975 \\
\hline 60 & 13847 & 2557 & 3,2620 & 5029 \\
\hline 70 & 13847 & 1687 & 2,4273 & 6400 \\
\hline 80 & 13847 & 975 & 1,8061 & 8207 \\
\hline 90 & 13847 & 915 & 1,3439 & 10984 \\
\hline 100 & 13847 & - & 1,0000 & 13847 \\
\hline \multicolumn{5}{|c|}{ Ąžuolynai; Nd augavietè / Oak Nd site index } \\
\hline 10 & 31506 & 32048 & 25,8282 & 2461 \\
\hline 20 & 31506 & 29854 & 19,2186 & 3193 \\
\hline 30 & 31506 & 25381 & 14,3005 & 3978 \\
\hline 40 & 31506 & 20087 & 10,6409 & 4849 \\
\hline 50 & 31506 & 14976 & 7,9178 & 5871 \\
\hline 60 & 31506 & 10633 & 5,8916 & 7152 \\
\hline 70 & 31506 & 7161 & 4,3839 & 8820 \\
\hline
\end{tabular}




\begin{tabular}{ccccc}
\hline 80 & 31506 & 4512 & 3,2620 & 11042 \\
\hline 90 & 31506 & 2528 & 2,4273 & 14021 \\
\hline 100 & 31506 & 1065 & 1,8061 & 18034 \\
\hline 110 & 31506 & & 1,3439 & 23444 \\
\hline 120 & 31506 & - & 10000 & 31506 \\
\hline
\end{tabular}

* Pateikta 6 lentelèje ir padauginta iš 0,7 dèl skalsumo;

** pateikta 7 lenteleje ir padauginti iš 0,7 dèl skalsumo ir iš 0,5 dèl iškrentančio tūrio panaudojimo.

kainos vertinimai daugiau nei 2 kartus didesni už piniginių srautų (2,3-2,6 karto). Skirtumą lemė tai, kad VKC vertina valstybinius miškus pagal faktiškai gautas grynąsias pajamas, kurių didžiausią dali sudaro pajamos už medieną iš III ir IV grupès miškų. VMT vertina visus miškus pagal medieną, tačiau saugomuose miškuose (I ir II grupès) yra sukaupti dideli medynų tūriai, kurie neturi įtakos grynosioms pajamoms.

10 lentelè. Miškų urẻdijų miškų vertinimų nominaliomis kainomis ir diskontuotų pinigų srautų metodu palyginimas

Table 10. The comparison of valuation of state forest enterprises' forests according to nominal prices and discounted cash flow methods

\begin{tabular}{c|c|c|c}
\hline $\begin{array}{c}\text { Vertinimo } \\
\text { data } \\
\begin{array}{c}\text { Evaluation } \\
\text { date }\end{array}\end{array}$ & $\begin{array}{c}\text { Mata- } \\
\text { vimo } \\
\text { vnt. } \\
\text { Unit }\end{array}$ & $\begin{array}{c}\text { Nominali } \\
\text { kaina* } \\
\text { Nominal } \\
\text { price }\end{array}$ & $\begin{array}{c}\text { Piniginių srautų } \\
\text { metodas** } \\
\text { Cash flow } \\
\text { method }\end{array}$ \\
\hline $2012-01-01$ & mln. LTL & 7597,0 & 3253 \\
\hline $2013-01-01$ & mln. LTL & 7709,2 & 2971 \\
\hline $2014-01-01$ & mln. LTL & 7883,7 & 2971 \\
\hline $2015-01-01$ & mln. $€$ & 2321,2 & 887 \\
\hline
\end{tabular}

*VMT, 2012; VMT, 2013; VMT, 2014; VMT, 2015;

**VKC, 2013; VKC, 2014; VKC, 2015.

Miškų vertinimo nominalių kainų metodų atitikimo tikrosios vertès nustatymo principams ir metodams apibūdinimas. Metodas visiškai neatitinka pagrindinio tikrosios vertès nustatymo principo, kad tikroji vertè yra vertinamo objekto rinkos kaina. Dabartiniai miško žemių ir medynų tūrio vertinimai visiškai nesusieti su jų rinkomis. Pinigu srautų diskontavimo metodas, kaip vienas iš galimų miškų tikrosios vertès nustatymo metodų, iš dalies realizuojamas nustatant nominalią miško žemių vertę. Tačiau medienos pajamų vertinimas šioje metodikoje nèra susietas su dabartinèmis medienos rinkomis. Medynų tūrio nominalūs ịkainiai nustatyti ne būsimųjų pajamų pagrindu jas diskontuojant, o dabartinių medynų tūrius dauginant iš jų nenukirsto miško kainų, kas tinka tik brandiems medynams.

\section{REZULTATŲ APTARIMAS}

Vertinant miško žemę pagal Faustmano formulę nederlingose $\mathrm{Na}$ augavietėse vertinimas mažesnis nei pagal nominalią kainą. Didejant augaviečių našumui, vertinimai kyla ir viršija vertinimus pagal nominalią kainą 2,7 karto $\mathrm{Nb}$ augavieteje, 1,9 karto Nc augavieteje ir 4,5 kartus Nd augavietëje (11 lentelè).

11 lentelè. Miško žemès ( $\mathbf{N a}, \mathbf{N b}, \mathbf{N c}, \mathbf{N d}$ augavietės) nominalios kainos palyginimas su vertinimais pagal Faustmano formulę $€ /$ ha

Table 11. Comparison of forest land (Na, Nb, Nc, Nd site indexes) nominal prices with the valuation according to the Faustman formula

\begin{tabular}{c|cc}
\hline \multirow{2}{*}{$\begin{array}{c}\text { Augaviete் } \\
\text { Site index }\end{array}$} & \multicolumn{2}{|c}{ Vertè $€ /$ ha / Value, $€ /$ ha } \\
\cline { 2 - 3 } & $\begin{array}{c}\text { Nominali kaina } \\
\text { Nominal price }\end{array}$ & $\begin{array}{c}\text { Faustmano formule } \\
\text { Faustman formula }\end{array}$ \\
\hline $\mathrm{Na}$ & 260,4 & 40 \\
\hline $\mathrm{Nb}$ & 376,2 & 627 \\
\hline $\mathrm{Nc}$ & 434,6 & 825 \\
\hline $\mathrm{Nd}$ & 463,4 & 2093 \\
\hline
\end{tabular}

* Perskaičiuota $3 \%$ diskonto norma.

Nominalią miško žemès kainą lèmè vidutinès grynosios miškų ūkio pajamos, diskonto norma ir augaviečių našumas. Miško žemès kainą pagal Faustmano formulę lemia medynų tūris kirtimo metu, tarpinių kirtimų laikas ir apimtys, medienos nenukirsto miško kaina, miškų atkūrimo ir administravimo išlaidos, diskonto norma. Lyginant nominalią žemès kainą su apskaičiuota pagal Faustmano formulę, diskonto norma suvienodinta skaičiuojant nominalias kainas su $3 \%$ norma 
(11 lentelè). Gautų rezultatų skirtumus lèmè taikytų augaviečiu produktyvumo îvertinimo metodų skirtumai. Nominalių kainų metodikoje tarp $\mathrm{Nd}$ ir $\mathrm{Na}$ augaviečių jis buvo 1,8 karto (1 lentelè), o dabar - 4,5 karto (6 lentelè).

Lyginant nominalią kainą su vertinimais pagal Dieterich formulę, išryškejo didžiausi skirtumai tarp jaunų ir brandžių medynų. Ypač dideli ąžuolynų vertinimo skirtumai - 10,3 karto - 20 metų medynų ir 4,7 karto - 120 metų (1 pav.).

Apskaičiuotos vidutinio skersmens (VMT, 2015) brandžių medynų nominalios ir nenukirsto miško kainos (2015 m. sausio 21 d.). Jos palygintos 2 pav. Brandžių medynų tūrio vertinimai nenukirsto miško kainomis kelis kartus didesni nei nominaliomis kainomis. Skiriasi ir santykiai tarp medžių rūšių vertinimų, ypač kietụjų lapuočių medynų ir eglynų.

Nominalią medynų tūrio kainą lèmè medžių rūšis, vidutinis medynų skersmuo, medienos nenukirsto miško kaina. Medynų vertè pagal Dieterich formulę apskaičiuota remiantis pajamų, gaunamų iškirtus brandų medyną, verte nenukirsto miško kainomis, kirtimų apyvarta, tarpinių kirtimų ir diskonto norma. Abiejų vertinimų būdų skirtumams įtakos turèjo nebrandžių medynų vertinimai bei pasikeitusios medienos kainos.

Miškų vertinimo rezultatus itin lemia diskonto norma. Palūkanų normos dydžio klausi- mai, nustatant medynų grynąją dabartinę vertę, buvo diskutuojami jau vèlyvaisiais viduramžiais (Burgsdorf, 1796; Jordan, 1800 ir kt.; pagal Moog, Bösch, 2013). Vokiečiu miškininkai siūlè įvairius diskonto normos nustatymo metodus. Siūlyta taikyti didesnes už rinkos normas, motyvuojant miškų ūkio rizika ir būtinumu gauti pelną. Dèl kapitalo rinkų netobulumo buvo teikiamos žemesnès nei rinkos palūkanų normos. Pasigirdo siūlymų taikyti tarpinę normą tarp mažiausios rizikos veiklos ir kapitalo rinkos palūkanų normų. Dar buvo siūlymų didinti palūkanų normą, priklausomai nuo medynų amžiaus klasès. Mažesnių nei kitose ūkio šakose diskonto normų taikymas miškininkystejje dažnai aptinkamas ši klausimą analizuojančiuose mokslo darbuose (Uilliams, 1991; Price, 1993; Klemperer et al., 1994; Brukas et al., 2001; Hepburn, Koundouri, 2007; Binkley, 2009; Grege-Staltmane, Tuherm, 2010). Aukščiausios diskonto normos (>7 \%) siūlomos taikyti greitai augančioms medžių rūšims. JAV taikoma 4-8 \%, Skandinavijos šalyse - 2-4\%, Vokietijoje - nuliné diskonto norma. Atlikę 56 diskonto normą lemiančių veiksnių analizę Lietuvoje, V. Brukas ir kt. (2001) siūlè Lietuvos valstybiniame miškų ūkyje taikyti iki $4 \%$ diskonto normą. Europos komisijos metodiniuose dokumentuose (EK, 2006) siūloma minimali socialiné diskonto norma $-3,5 \%$. Yra

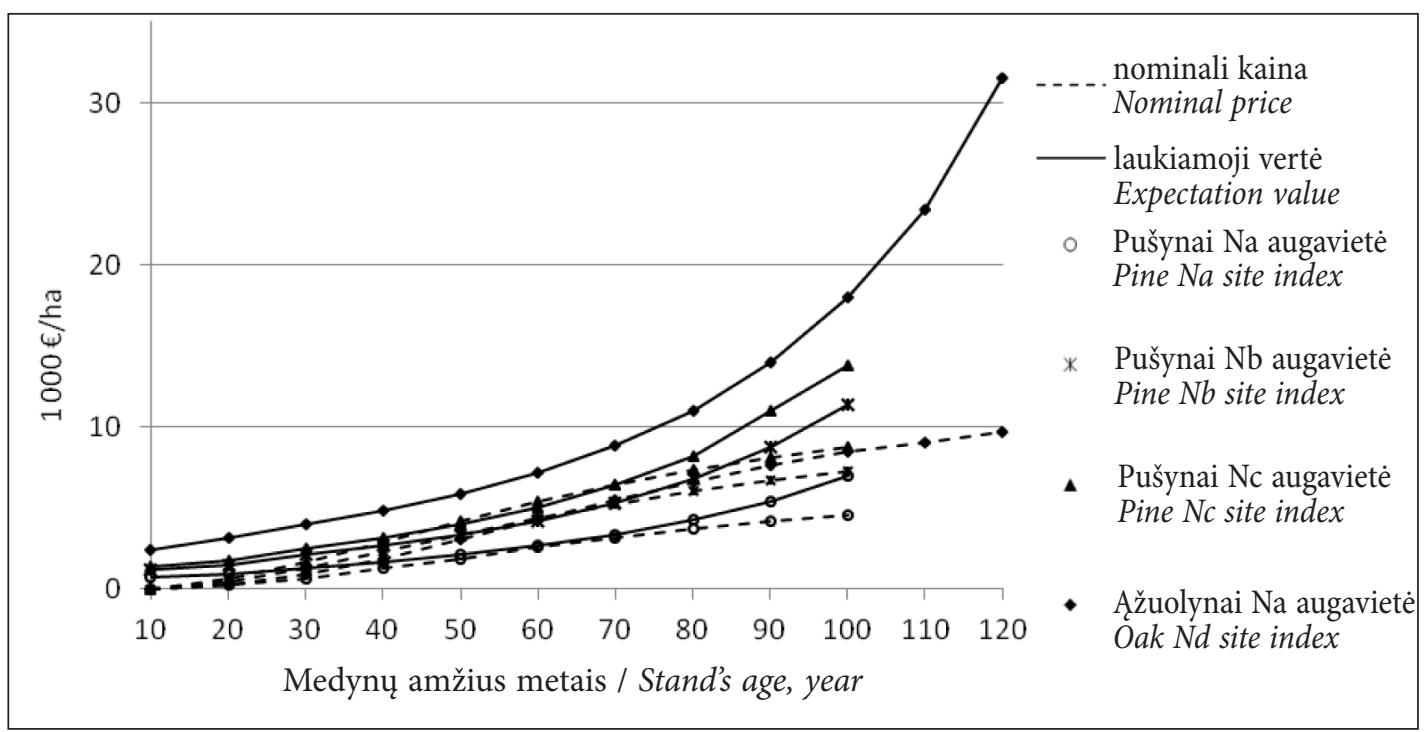

1 pav. Medynų tūrio (skalsumas 0,7) nominalios kainos palyginimas su vertinimais pagal Dieterich formulę

Fig. 1. Comparison of the nominal price of stand volume with the valuation according to the Dieterich formula 


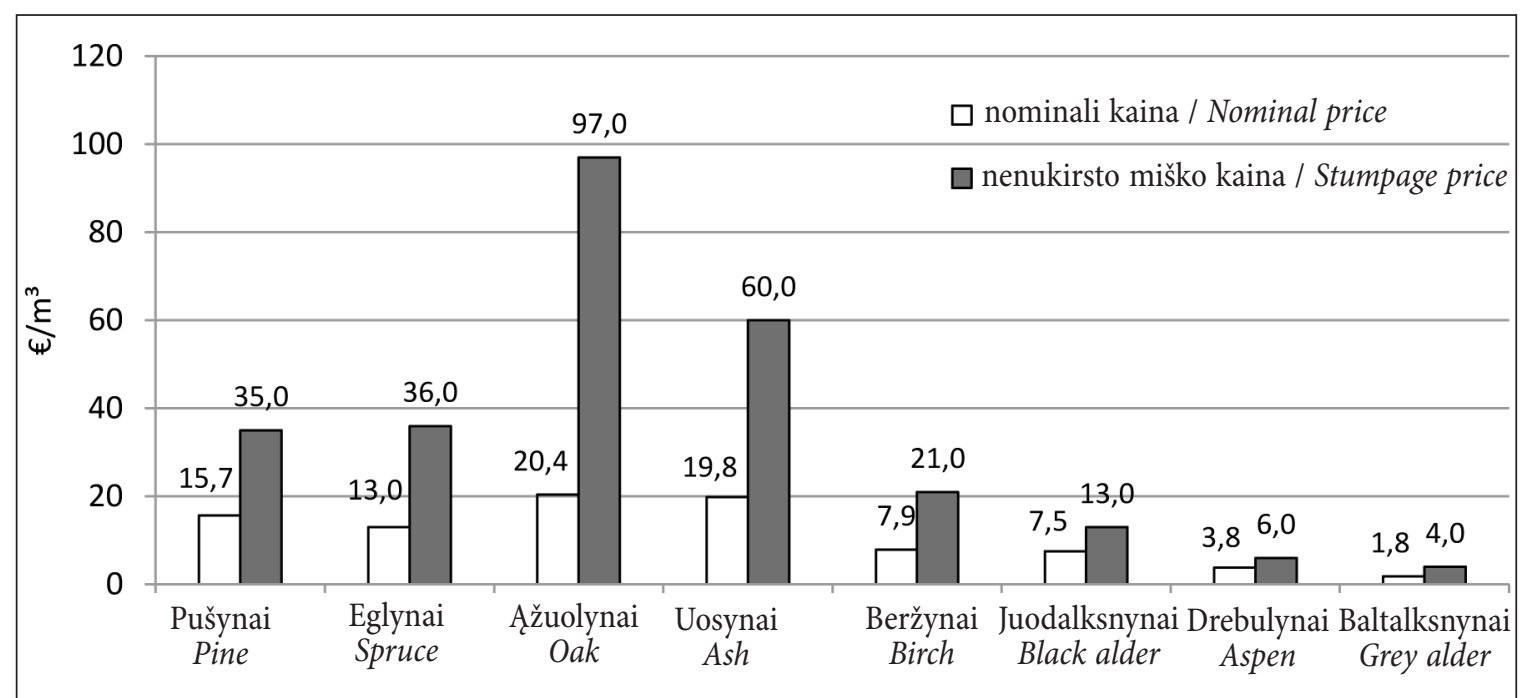

2 pav. Brandžių medynų tūrio nominalios kainos palyginimas su nenukirsto miško kaina

Fig. 2. Comparison of the mature stand volume nominal price with the stumpage price

teorijų, pagrindžiančių mažejančią diskonto normą ilgejjant diskontavimo laikotarpiui (Weitzman, 1998). Šiame tyrime taikyta $3 \%$ diskonto norma, kaip dažniausiai rekomenduojama literatūroje. Palyginamumui užtikrinti nominalių kainų metodo rezultatai apskaičiuoti pagal šią normą.

Tyrimų rezultatai parodè, kad VMT apskaičiuojama Lietuvos miškų vertẻ negali būti traktuojama kaip tikroji vertè. Šie vertinimai nèra grindžiami miško rinkų duomenimis. Medynų tūriams vertinti netaikomas ir diskontuotų pinigų srautų metodas. Brandžių medynų vertinimai kelis kartus skiriasi nuo vertinimų pagal nenukirsto miško kainas. Neatitinka tikrovès ir santykiai tarp atskirų medžių rūšių tūrio vertinimų. Visai pagrịstai VKC, vertindamas miškų urèdijų ekonominę veiklą, taiko ne nominalios kainos, o diskontuotų pinigų srautų metodą. Diskontuotų pinigu srautų metodas yra plačiai taikomas vertinant miškus ir turi ilgametes tradicijas. Atlikta daug tyrimų miškų vertinimo finansinès apskaitos klausimais, parodančių pinigų srautų diskontavimo metodų taikymo galimybes (Jansson, Fagerström, 2003; Bigsby, Willemse, 2004; Penttinen ir kt., 2004; Burnside, 2005; Penttinen, Rantala, 2008; Svensson ir kt., 2009; FPP, 2011).

Turto vertinimo metodologija yra apibrèžta tarptautiniuose bei nacionaliniuose turto ir verslo vertinimo dokumentuose (standartuose, metodikose). Metodai yra skirstomi $\mathfrak{i}$ tris grupes: rinkos, išlaidų ir pajamų (Bendrieji..., 1995). Dèl miškų ūkio specifikos (ilgas medynų auginimo laikotar- pis ir miškų naudos kompleksiškumas) reikejjo bendrus ekonominius metodus adaptuoti mišku ūkyje. Atlikta daug mokslinių ir praktinių darbų sprendžiant miškų, kaip turto, vertinimo uždavinius. Jie apibendrinami sudarant mišku vertinimo standartus. Tarptautinè vertinimo standartų taryba $2012 \mathrm{~m}$. parengè techninių nurodymų projektą "Miškų vertinimas“ (IVSC, 2012). Jame nurodoma, kad dèl miškų ịvairovès retai pavyksta tiesiogiai palyginti vertinamą mišką su jau parduotu. Tačiau pirkimų ir pardavimų analizé gali būti svarbus vertinimo įrankis. Tokios analizès nauda gali pasireikšti išaiškinant pardavimo kainą lemiančius veiksnius: medžių brandumą, miško plotą ir padèti, medžių rūšis ir kt. Ankstesni pirkimai gali būti naudingi ir tais atvejais, kai vertinami analogiški miškai, bet jau yra pasikeitusios medienos produktų kainos. Tada atsižvelgiama i̇ šių kainų pokyčius. Vertinant miškus pajamų metodais taikoma grynųjų diskontuotų pajamų skaičiavimo technika. Pajamos dažniausiai vertinamos nenukirsto miško kainomis, nustatant datą, kada laukiami kirtimai. Pinigu srautuose atspindimos miškuc įveisimo, priežiūros ir apsaugos išlaidos per laikotarpi nuo mišku ịveisimo iki medynų iškirtimo. Dideli miškai ar plantacijos dažniausiai tvarkomi siekiant nepertraukiamų medienos srautų, todèl vertinant reikia atsižvelgti ị miškų amžiaus struktūras. Išlaidų metodai grindžiami vertinamam objektui atkurti reikalingų išlaidų kalkuliacijomis. Išlaidų metodas labiausiai tinkamas neseniai pasodintiems 
miškams. Dažniausiai nustatomos tokios išlaidų rūšys: žemès įsigijimo, infrastruktūros sukūrimo, dirvos paruošimo, sodmenų pirkimo ir sodinimo. Standarto „Miškų vertinimas“ projekte numatoma vertinimo galimybe pagal visus tris metodus, vèliau lyginant ir analizuojant gautus rezultatus. Reikètų adaptuoti diskontuotų pinigų srautų vertinimo metodus Lietuvos sąlygomis užtikrinant miškų vertinimus, artimesnius tikrosioms rinkos vertèms.

\section{IŠVADOS}

1. Lietuvos miškų ūkyje plačiausiai taikomi du miškų ekonominio vertinimo metodai: 1) nominalios kainos; 2) diskontuotų pinigų srautų. VMT taikomų nominalių kainų metodu vertinama visų Lietuvos miškų kiekvieno miško sklypo žemė ir medyno tūris atskirai. Miško žemès vertinimo pagrindą sudaro $1990 \mathrm{~m}$. grynosios pajamos, diferencijuotos pagal augavietes, remiantis jų produktyvumu, ir medynų tūrio to laikotarpio nenukirsto miško kainos. VKC vertindama visus miškų urèdijų miškus taiko diskontuotų pinigų srautų rodikli.

2. VMT taikomas miškų vertinimo nominalių kainų metodas neatitinka tikrosios miškų vertės nustatymo principų. Šie vertinimai nèra grindžiami miško rinkų duomenimis. Medynų tūriams vertinti netaikomas ir diskontuotų pinigu srautų metodas. Paskutinè miško žemès nominalių kainų indeksacija atlikta 1995 m., o medynų tūrio $-2010 \mathrm{~m}$.

Gauta 20151023

Priimta 20160609

\section{LITERATŪRA}

1. Aleknavičius A. 2007. Nekilnojamojo turto vertinimas ir rinkotyra. Akademija. 64 p. [žiūrèta 201509-23]. Prieiga per internetą: http://vuzf.asu.lt/ wp-content/uploads/sites/6/2015/01/nt_vertinimas_ir_rinkotyra_0.pdf

2. Bajoriūnaitè B. 2006. Naujas turto jivertinimo būdas - tikroji verte. Apskaitos ir mokesčiu apžvalga [žiūrèta 2012-04-07]. Prieiga per internetą: http:// www.buhalteris.lt

3. Bendrieji turto vertinimo principai. 1995. Valstybès žinios. 1995-04-05, Nr. 29-652.
4. Bigsby H., Willemse B. 2004. Internationalisation and the Valuation of Forest Assets: Discussion Paper. Canterbury, New Zealand: Lincoln University. 13 p.

5. Binkley C. S. 2009. The sensitivity of the value of timberland assets to changes in the discount rate [žiūrèta 2013-10-26]. Prieiga per internetą: http:// www.ifiallc.com/PDFs/The-Sensitivity-of-theValue-of-Timberland-Assets-to-Changes-in-theDiscount-Rate.pdf

6. Brukas V., Helles F., Tarp P., Thorsen B. J. 2001. Discount rate and harvest policy: implications for the Baltic forestry. Forest Policy and Economics. Vol. 2(2). P. 143-156.

7. Burnside A. 2005. IAS 41 and the Forest Industry: Bachelor Thesis. School of Economic and Commercial Law, Göteborg University. 56 p. [žiūrèta 2013-10-01]. Prieiga per internetą: https://gupea. ub.gu.se/bistream/2077/1524/1/04-05-78.pdf

8. EK. 2006. Ekonominès naudos analizès atlikimo metodines gairès. Metodiniai darbo dokumentai. 22 p. [žiūrèta 2014-06-16]. Prieiga per internetą: http://ec.europa.eu/regional_policy/sources/docoffic/2007/working/wd4_cost_lt.pdf

9. Faustmann M. 1849. Berechnung des Werthes, welchen Waldboden, sowie noch nicht haubare Holzbestnde für die Waldwirthschaft besitzen. AFJZ. Vol. 15(12). P. 441-455.

10. Ferguson J., Leech J. 2007. Forest valuation and the AASB 141 accounting standard. Australian Forestry. Vol. 70(2). P. 125-133.

11. FPP (Forest, Paper and Packaging). 2011. Forest Industry: Application Review of IAS-41, Agriculture: The Fair Value of Standing Timber [žiūrèta 201306-20]. Prieiga per internetą: http://www.pwc. com.uy/en_UY/uy/publicaciones/assets/forest-industry.pdf

12. Grege-Staltmane E. 2010. Challenges in accounting the forests - a Latvian case study. Annals of Forest Research. Vol. 53(1). P. 51-58.

13. Hepburn C. J., Koundouri P. 2007. Recent advances in discounting: implications for forest economics. Journal of Forest Economics. Vol. 13(2-3). P. 169189.

14. IFA. 2012. A Standard for Valuing Commercial Forests in Australia. Version 2.1. The Institute of Foresters of Australia [žiūrèta 2016-03-09]. Prieiga per internetą: http://www.forestry.org.au/kcfinder/ upload/files/A\%20standard\%20for\%20valuing\%20 forests $\% 20 \mathrm{in} \% 20$ Australia\%20ACFA \%20July\%20 2012.pdf

15. IVSC (International Valuation Standards Council) 2012. The Valuation of Forests. Exposure Draft [žiūrèta 2015-09-23]. Prieiga per internetą: http:// www.ivsc.org/sites/default/files/Forestry\%20 TIP\%20Exposure\%20Draft_0.pdf 
16. Jansson A. M., Fagerström A. 2003. Accounting for Forest Assets: The Case of IAS-41 and Fair Value. Turku, Finland: Abo Akademi University. 44 p.

17. Kenstavičius J., Kuliešis A. 1983. Medynų prekinè struktūra. Kn.: Miško taksuotojo žinynas. Vilnius. P. 77-79.

18. Klemperer W. D. 1996. Forest Resource Economics and Finance. New York. 552 p.

19. Kuliešis A. 1993. Lietuvos medynu prieaugio ir jo panaudojimo normatyvai. Kaunas. 383 p.

20. Lord R. 2014. What is Fair Market Value in the Timber Industry? Presented at OSCPA Forest Products Conference. Oregon [žiūrèta 2012-0309]. Prieiga per internetą: http://www.masonbruce.com/wp-content/uploads/2014/07/MarketValue-ORCPA-Forest-Prod-Conference-2014.pdf

21. Macedo D. 2012. The Fair Value of Forestry: Analysis of Precious Woods and Green Resources: Dissertation [žiūrèta 2016-03-09]. Prieiga per internetą: http://www.repositorio.ucp.pt/bitstream/10400. 14/10196/1/Master\%20Thesis\%20Fair\%20Value.pdf

22. Mališauskas V. (ats. red.). 1975. Miško žemiu ekonominis vertinimas. Vilnius. $192 \mathrm{p}$.

23. Mantel W. 1982. Waldbewertung. BLV Verlagsgesellsehaft. München. 343 p.

24. Mizaras S. 1993. Mišku ūkis ir rinkos ekonomika. Kaunas. 152 p.

25. Mizaras S. 1997. Stačio miško kainų skaičiavimo metodas. Miškininkystè. Nr. 2(40). P. 80-85.

26. Mizaras S., Brukas V., Mizaraitè D. 2015. Mišku tvarkymo darnumo vertinimas: ekonominiai ir socialiniai aspektai. Kaunas. 256 p.

27. Moog M., Bösch M. 2013. Interest rates in the German forest valuation literature of the early nineteenth century. Forest Policy and Economics. Vol. 30. P. 1-5.

28. Penttinen M., Latukka A., Meriläinen H., Salminen O., Uotila E. 2004. IAS fair value and forest evaluation on farm forestry. Human Dimension of Family, Farm and Community Forestry: International symposium Proceedings. Washington State University. P. 303-307.

29. Penttinen M., Rantala O. 2008. The International Financial Reporting Standards (IFRS) accounting system as applied to forestry. Working Papers of the Finish Forest Research Institute. 38 p. [žiūrèta 2013-06-20]. Prieiga per internetą: http://www.metla.fi/julkaisut/workingpapers/2008/mwp093.pdf
30. Price C. 1993. Time, Discounting and Value. Oxford, UK. 180 p.

31. Riepšas E., Laurinavičius E. 2009. Miško atkūrimo technologijų ekonominè analizè. Ľ̌ ŪU mokslo darbai. Nr. 84. P. 29-38.

32. Svensson A., Nylén A., Gunnevik A. 2008. How Fair is Fair? The Swedish Forest Industry Application of the IAS-41-Agriculture: Master's Thesis. Stockholm School of Economics. 65 p. [žiūrèta 2013-06-20]. Prieiga per internetą: http://arc.hhs.se/download. aspx?MediumId=652

33. Uilliams M. R. V. 1991. Ratsional'noe ispol'zovanie lesnykh resursov. Moskva: Ekologiya. $126 \mathrm{~s}$.

34. VKC. 2013. Lietuvos valstybès valdomu imoniu veikla 2012 metais. Metine ataskaita. 108 p. [žiūrèta 201509-23]. Prieiga per internetą: http://vkc.turtas.lt

35. VKC. 2014. Lietuvos valstybès valdomu imoniu veikla 2013 metais. Tarpinė ataskaita: sausis-gruodis. 55 p. [žiūrèta 2015-09-23]. Prieiga per internetą: http://vkc.turtas.lt

36. VKC. 2015. Lietuvos valstybès valdomu imoniu veikla 2014 metais. Metiné ataskaita. 130 p. [žiūrèta 201509-23]. Prieiga per internetą: http://vkc.turtas.lt

37. VMT. 2010. Miškotvarkos darbu vykdymo instrukcija [žiūrèta 2015-09-23]. Prieiga per internetą: http://www.infolex.lt/ta/132288

38. VMT. 2012. Valstybine mišku apskaita 2012-0101 [žiūrèta 2015-09-23]. Prieiga per internetą: http://www.amvmt.lt/20120101/20120101.aspx?\&MID=0\&AMID=704

39. VMT. 2013. Valstybine mišku apskaita 201301-01 [žiūrèta 2015-09-23]. Prieiga per internetą: http://www.amvmt.lt/Images/Veikla/STAT/ Apskaita/2013.01.01/14\%20skyrius/14_2.txt

40. VMT. 2014. Valstybine mišku apskaita 2014-0101 [žiūrèta 2015-09-23]. Prieiga per internetą: http://www.amvmt.lt/20120101/20120101.aspx?\&MID=0\&AMID=839

41. VMT. 2015. Valstybine mišku apskaita 2015-0101 [žiūrèta 2015-10-19]. Prieiga per internetą: http://www.amvmt.lt/20150101/20150101.aspx?\&MID=0\&AMID=885.

42. Weitzman M. L. 1998. Why the far distant future should be discounted at its lowest possible rate. Journal of Environmental Economics and Management. Vol. 36(3). P. 201-208. 


\section{Stasys Mizaras, Diana Lukminè \\ THE RELEVANCE OF THE NOMINAL PRICE METHOD FOR FOREST VALUE ASSESSMENT IN LITHUANIA}

\section{Sum mary}

The issue how to evaluate Lithuanian forests as financial assets exists in accounting. The method of nominal price is used by the State Forest Service for the evaluation of forest economic value through the forest cadastre. There are suggestions for these assessments to be considered as the real forest value and to be used in accounting. The Governance Coordination Centre, analysing the efficiency of forest enterprises, assesses the economic value of their forests with the help of the Discounted Cash Flow (DCF) method. These estimations differ more than two times.

The aim of the present research is to assess the appropriateness of the nominal price method for the fair determination of the value of Lithuanian forests. The objectives of the research are the following: 1) to ascertain the relevance of the nominal price method for the forestland and forest stand value assessment to fair value assessment principles; 2) to assess the forest land and forest stand value by using the nominal price method and the Discounted Cash Flow (DCF) method; 3) to perform a comparative analysis of forest values estimated by the nominal price method and the Discounted Cash Flow (DCF) method.

The results showed that the nominal price method for forest value assessment did not comply with fair forest assessment principles, because this method is not associated with the trends of wood market prices. The Discounted Cash Flow (DCF) method is dominating in the global forest assessment theory and practical assessment of forest value, additionally supplemented by other assessment methods (market, income and expenses). It is necessary to create a monetary forest assessment methodology in Lithuania, which would be suitable for financial analysis of forestry entities.

Keywords: forests, monetary value, nominal price, cash flow, accounting, discount rate 